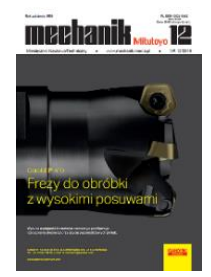

How to cite this article:

Authors: Piotr Szablewski, Tomasz Dobrowolski, Tadeusz Chwalczuk

Title of article: „, Optimization of Inconel 718 milling strategies”

Mechanik, No. 12 (2019)

DOI: https://doi.org/10.17814/mechanik.2019.12.112

\title{
Optimization of Inconel 718 milling strategies
}

\author{
PIOTR SZABLEWSKI \\ TOMASZ DOBROWOLSKI \\ TADEUSZ CHWALCZUK *
}

Dr inż. Piotr Szablewski, piotr.szablewski@pwk.com.pl, https://orcid.org/0000-0003-2435-2126 - Pratt \&Whitney Kalisz, Polska; Państwowa Wyższa Szkoła Zawodowa, Kalisz, Polska

Mgr inż. Tomasz Dobrowolski, tomasz.dobrowolski@pwk.com.pl - Pratt \& Whitney Kalisz, Polska

Mgr inż. Tadeusz Chwalczuk, tadeusz.chwalczuk@put.poznan.pl, https://orcid.org/0000-0002-4009-0552 - Politechnika Poznańska,

Poznań, Polska

This paper applies to the tests of the machining of a part made of supper alloy - nickel alloy - Inconel 718, using a monolithic carbide cutter. The paper includes a different versions of cutting methods with variable cutting parameters and machining strategies. The used sustainable machining process allowed to obtain control over the tool wear.

KEYWORDS: Inconel 718, tool wear, milling

\section{Introduction}

The material under the trade name Inconel 718 belongs to the group of nickel-based superalloys. Nickel content in such alloys can reach up to 70\%. One of the properties of the Inconel 718 alloy is low thermal conductivity coefficient (11.4 W/mK), which impedes the removal of heat from the cutting zone, which is largely the reason for accelerated wear of the cutting edge $[1,6,7]$. Another property of this alloy is strengthening during machining. This means that in subsequent passes, the tool cuts a material that has a hardness of up to 10 HRC greater than the native material. This property would suggest machining a super alloy with the greatest depth of cut, unfortunately this parameter is determined by another property, namely high tensile strength $(1310 \mathrm{MPa})[3,9]$.

Corrosion resistance and the possibility of using in the temperature range from $-250{ }^{\circ} \mathrm{C}$ to $700{ }^{\circ} \mathrm{C}$ cause that this material is widely used for the production of aircraft engine parts in their hot sections $[2,8]$.

Research on the impact of stresses introduced into the surface layer during cutting on tool life was conducted by the authors of the work [4], who confirm that the amount of stress generated should be minimized. A worn tool puts much more stress than a new cutting edge.

Optimization of cutting processes is the subject of many studies. This topic was dealt with by authors of the work [5]. They noted that accurate preparation of the material model is very labor-intensive. Unfortunately, production implementations show that the machinability of the material, even from one source but from different melts, is varied.

\section{Scope, conditions and technique of research}

The tests concerned concurrent milling of a bearing housing type element made of Inconel 718 alloy. A UDDE1600A5ARB KC643M toroidal milling cutter with AlTiN multilayer coating (applied by the PVD method) with a diameter of $16 \mathrm{~mm}$ and number of cutting edgees $\mathrm{z}=5$ with the HSK-A100-HMC32S-115 holder was used. Cutting data, such as cutting speed vc, feedrate f and milling depth ap, remained constant during testing. The milling width ae was changed. Milling tests were carried out using a cooling lubricant ( $6 \%$ emulsion). The wear of cutting edges was recorded on the Zoller Venturion 450 instrument. The $V B B$ and $K E$ parameters were evaluated.

The CAD/CAM system developed a machined part model that enabled the design and evaluation of various optimization strategies during concurrent milling (fig. 1). 


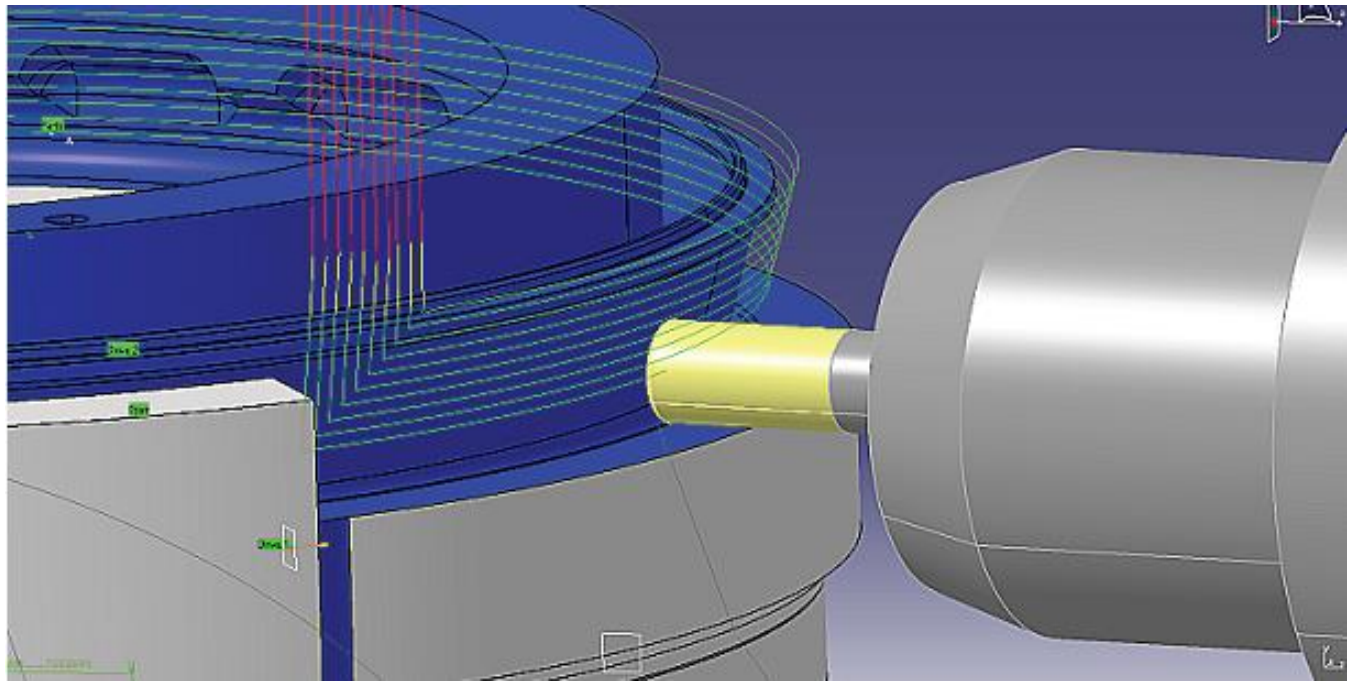

Fig. 1. Example view of the generated tool path in the Catia V5R22 application

Three machining strategies have been designed in the Catia application:

- concurrent milling with a fixed milling position in $\mathrm{Z}$ axis,

- concurrent milling with a variable milling position in $\mathrm{Z}$ axis,

- concurrent milling with a variable position of the mill in the axis $\mathrm{Z}$ and $30 \%$ increased milling width ae.

The correctness of the generated tool path in terms of collision and kinematic movements of the machine tool was checked in MSG-Catia-NC Machine Tool Simulation Product (fig. 2).

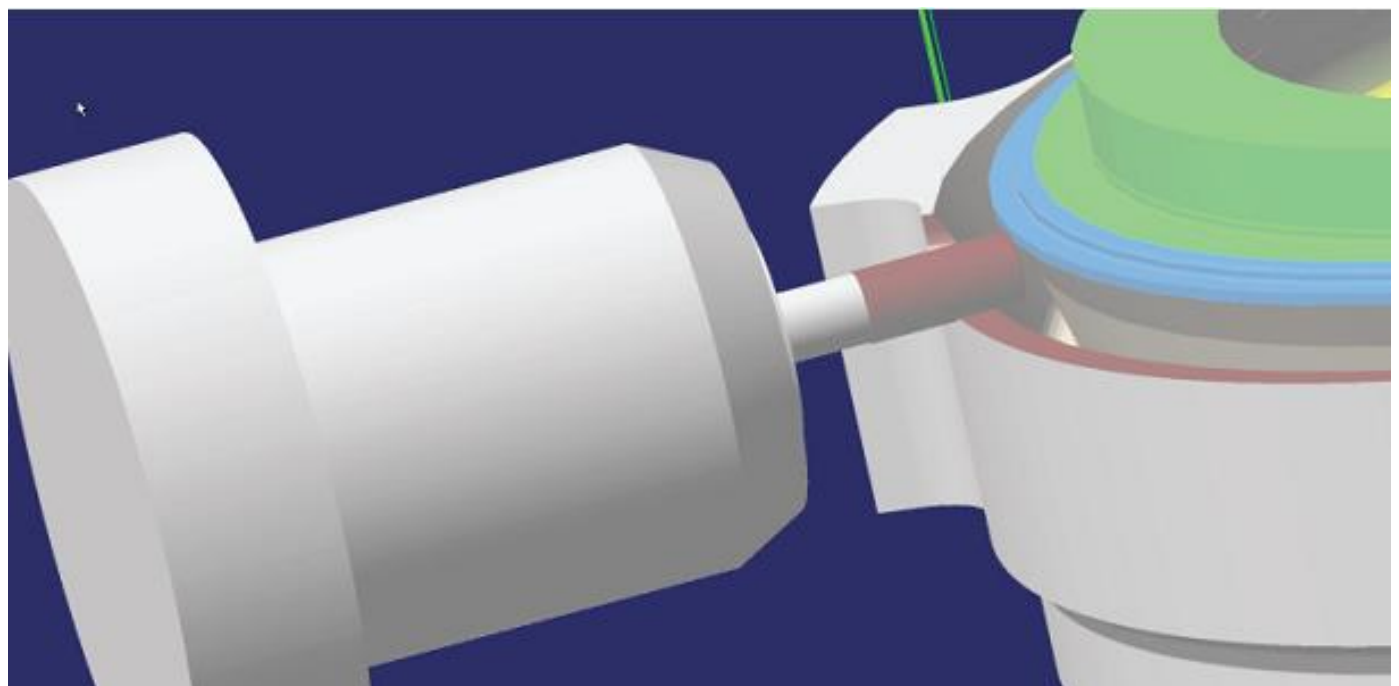

Fig. 2. Verifying the correctness of the generated tool path in the MSG-Catia-NC Machine Tool Simulation Product module

\section{Analysis of test results}

In the first considered variant, machining was stopped after $\mathrm{t}_{\mathrm{s}}=44 \mathrm{~min} 11 \mathrm{~s}$ due to the observed increased load on the milling spindle, which was caused by wear of the tool. Wear at the rake surface is shown in fig. 3 . Its value, depending on the cutting edges number, was in the range $V B_{B}=1.362 \div 1.495 \mathrm{~mm}$.

In the second variant, the tool removed the material to be processed. Tool operating time $t_{s}=49 \mathrm{~min} 8 \mathrm{~s}$. Wear at the rake surface in this variant is shown in fig. 4 . There was very high concentrated wear in both variants 1 and 2 . 


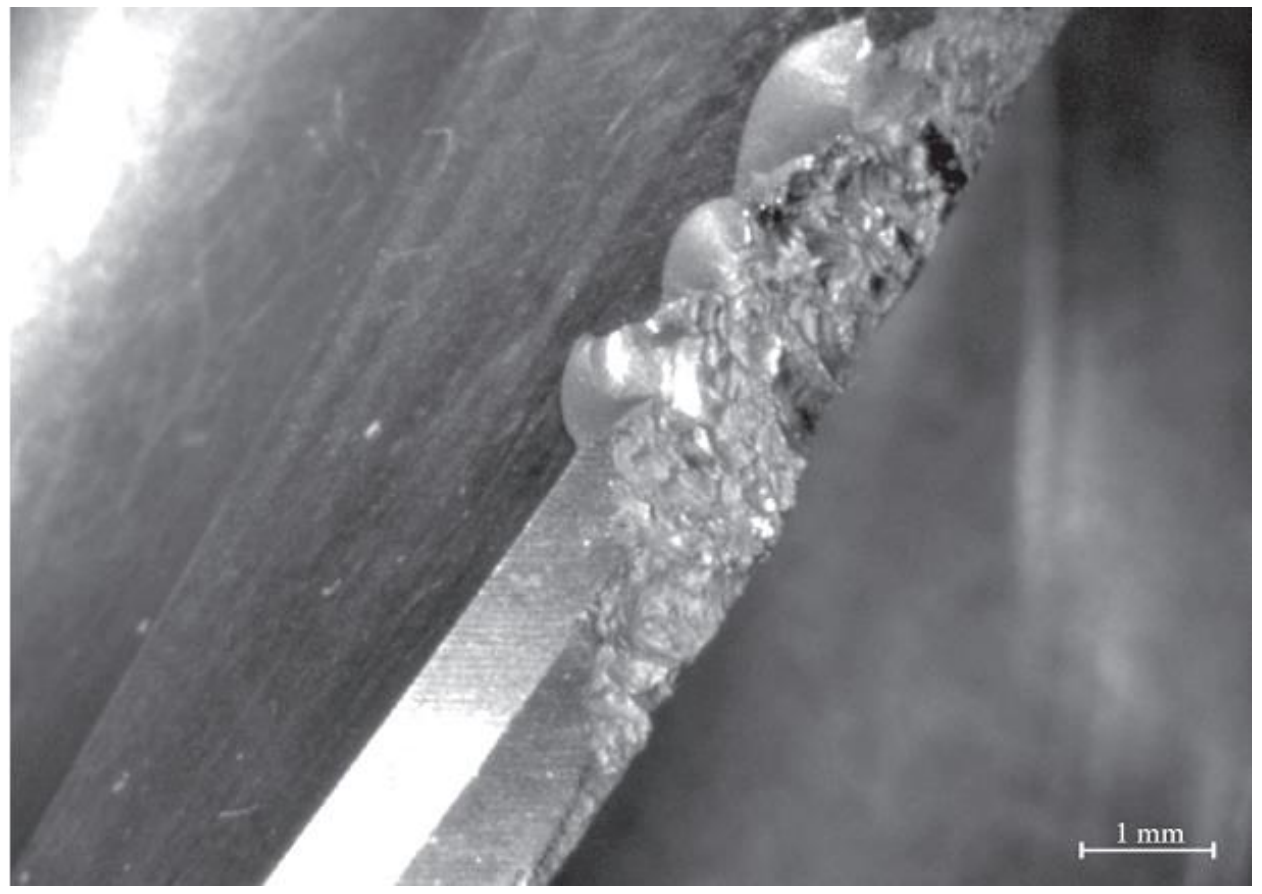

Fig. 3. Application surface after machining time ts $=44 \mathrm{~min} 11 \mathrm{~s}$ in variant $1\left(V B_{B}=1.362 \mathrm{~mm}\right)$

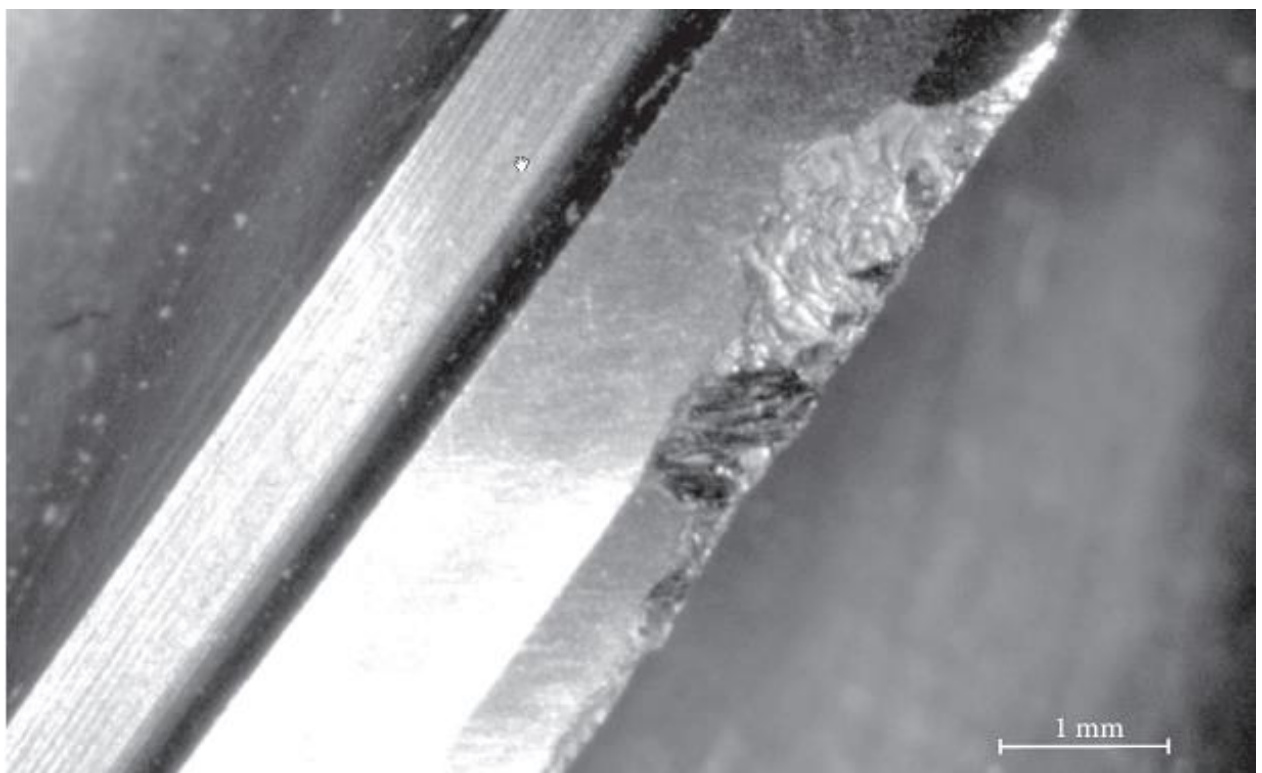

Fig. 4. Application surface after machining time $t_{s}=49 \mathrm{~min} 8 \mathrm{~s}$ in variant $2\left(V B_{B}=0.524 \mathrm{~mm}\right)$

Increasing the cutting width ae by $30 \%$ (in variants 1 and 2, it was $1.73 \mathrm{~mm}$ ) to the value of $2.249 \mathrm{~mm}$ had a positive effect on the condition of the tool after completing the full machining cycle (fig. 5).

Results of $V B B$ cutting edge wear measurements are presented in fig. 6 . It clearly shows that the most favorable machining strategy due to the durability of the cutting edge was used in option 3. 


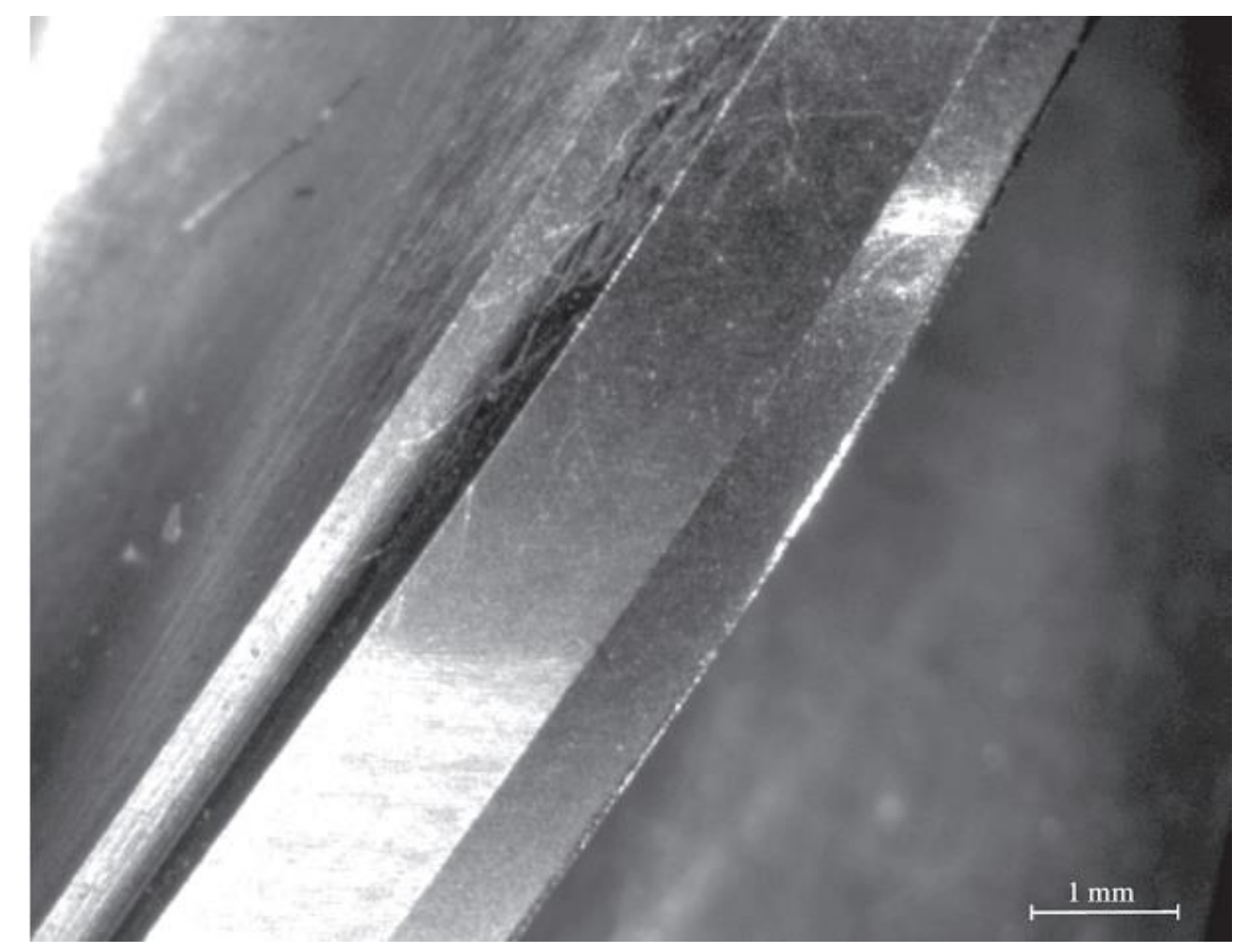

Fig. 5. Application surface after machining time $t_{s}=38 \mathrm{~min} 1 \mathrm{~s}$ in variant $3\left(V B_{B}=0.133 \mathrm{~mm}\right)$

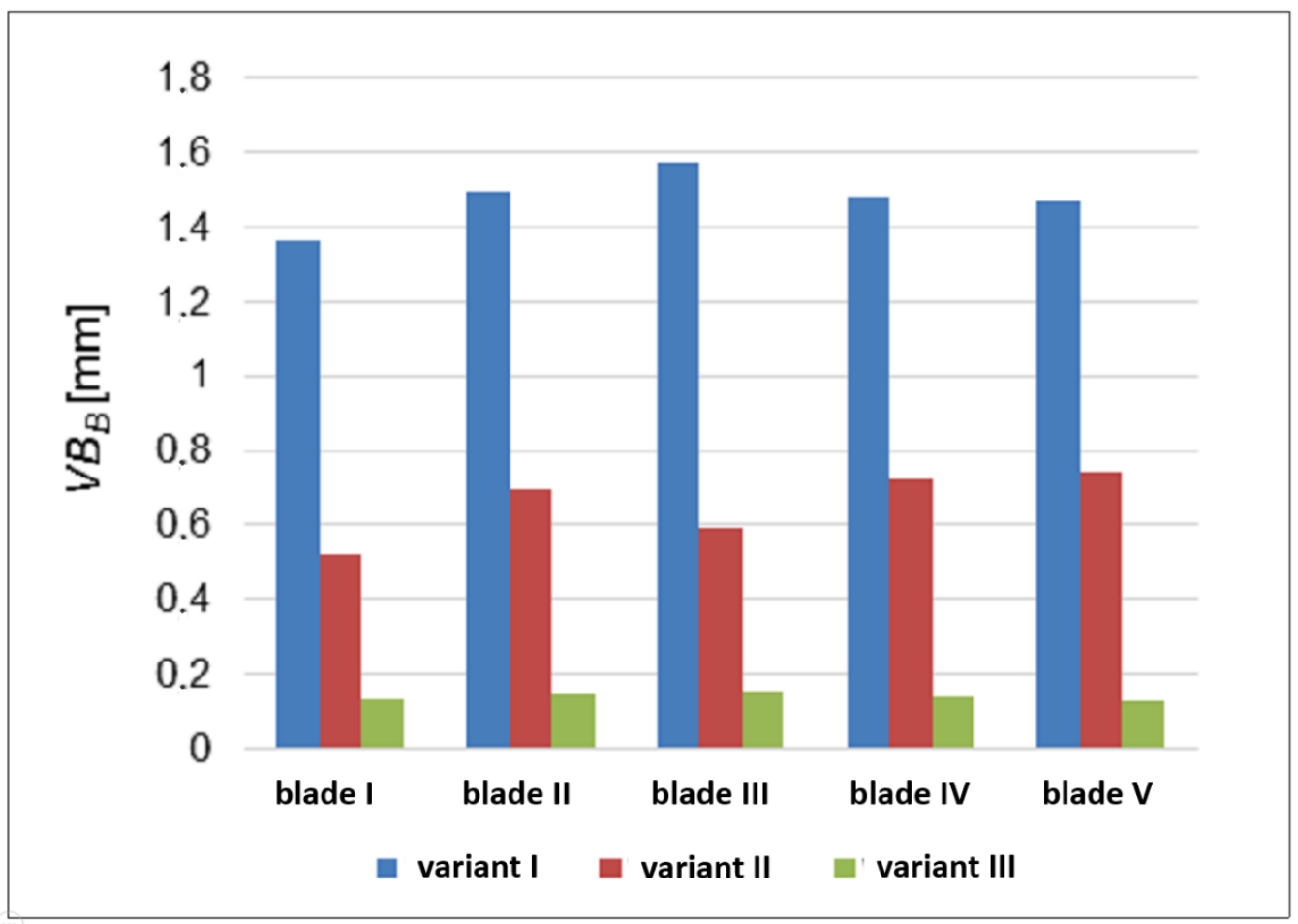

Fig. 6. Wear indicator of cutting teeth on the VBB rake after the machining cycle 


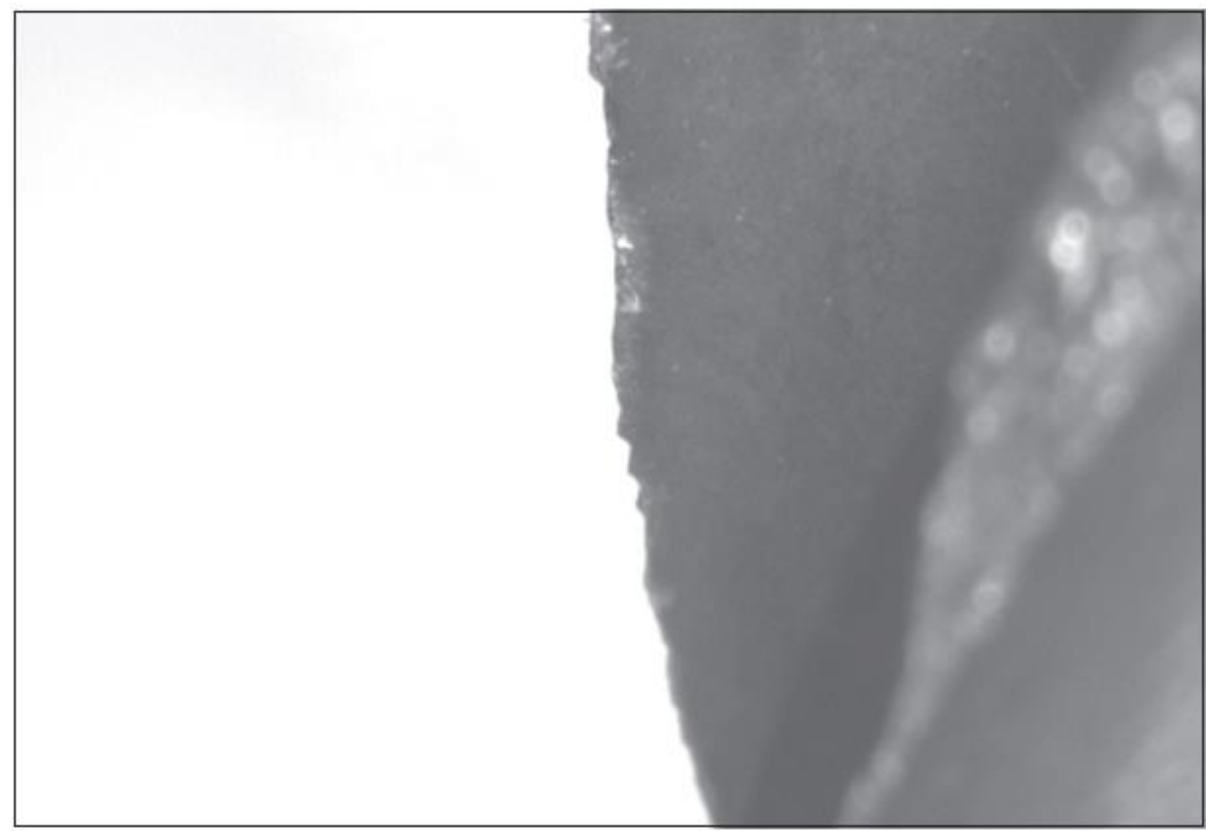

Fig. 7. Rake surface after machining time $t_{s}=44 \min 11 \mathrm{~s}($ variant 1$)$

When observing the cutting edge from the rake face in variants 1 and 2, a large retraction of the cutting edge can be seen, which is the result of its wear on the rake surface (figs. 7-8).

Variant 3 did not record any signs of wear on the cutting edges such as variants 1 and 2 . There are local traces as a result of flowing chip, but there are no such large fractures and notches of the cutting edge material as in the first two cases.

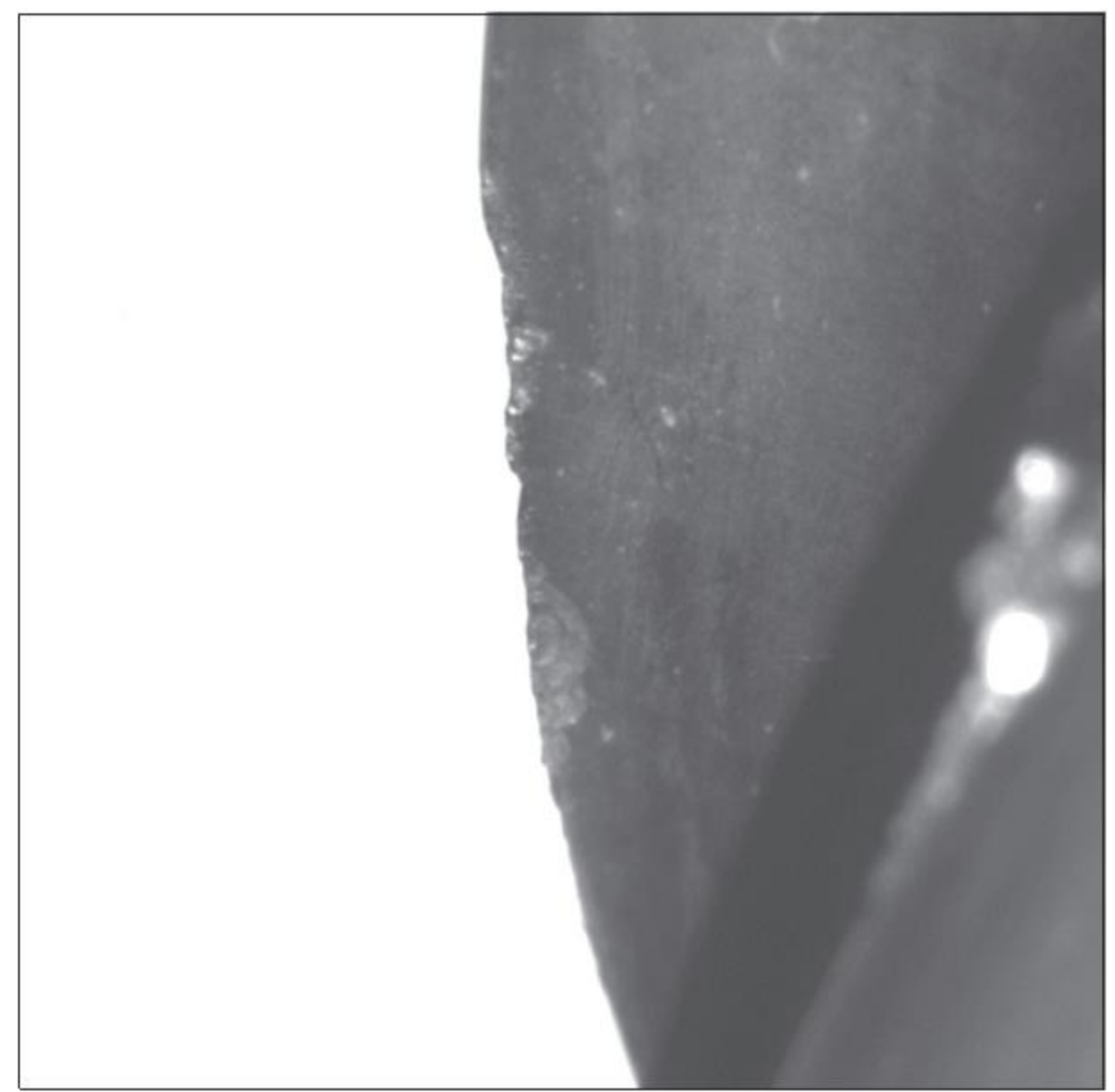

Fig. 8. Rake surface after machining time $t_{s}=49 \mathrm{~min} 8 \mathrm{~s}$ (variant 2) 


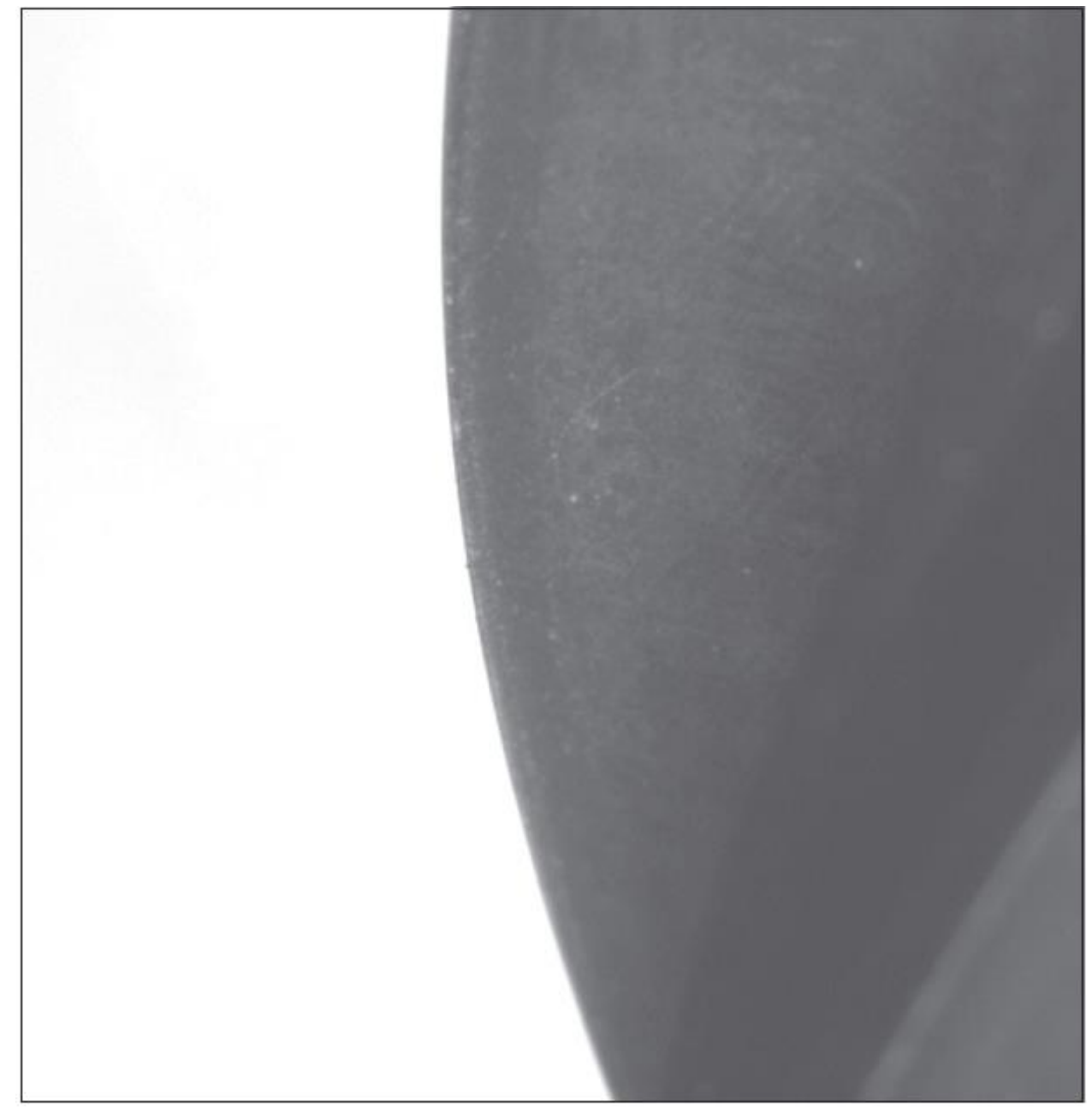

Fig. 9. Rake surface after machining time $t_{s}=38 \mathrm{~min} 1 \mathrm{~s}$ (variant 3 )

Results of the $K E$ retraction measurements are shown in fig. 10. Similarly to the analysis of wear on the rake surface, here also the highest values were recorded for the first variant, while the lowest ones for the variant 3.

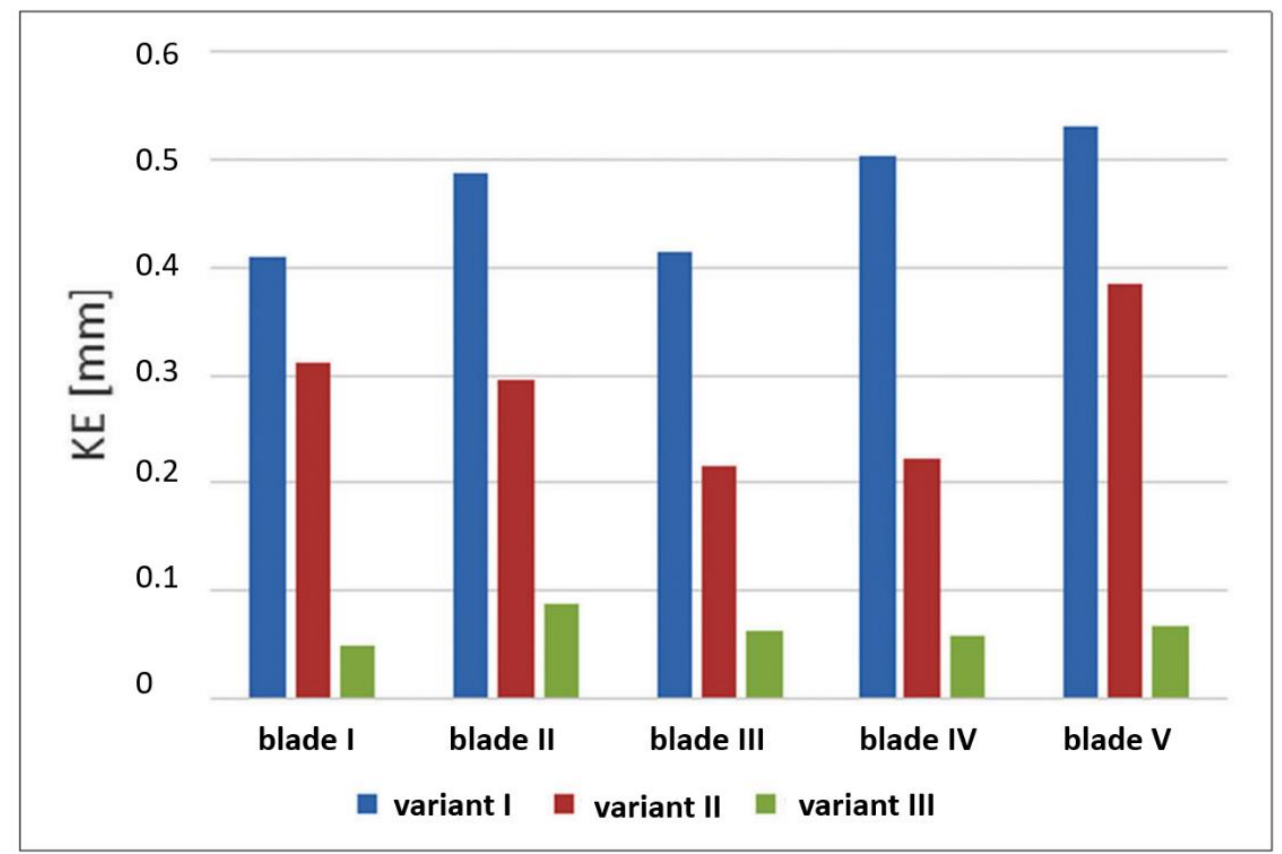

Fig. 10. $K E$ retraction values for cutting edges after the machining cycle 


\section{Summary}

Increasing the cutting width ae allowed to shorten the time of engagement of the cutting edge in the material, which probably has an impact on lower wear of the cutting edges. However, the decisive factor for significantly lower cutting edge wear in the third machining variant was the number of tool entries into the material. Increasing the cutting width from $1.73 \mathrm{~mm}$ to $2.249 \mathrm{~mm}$ has reduced this number from 65 to 50 . As stated earlier, Inconel 718 strengthens during machining, which increases the hardness of material being cut. Reducing the number of passes of the cutting tool with the same volume of material to be removed favorably affects the wear of the cutting edge.

Comparison of variants 1 and 2 shows that it is beneficial to change the position of the milling cutter in the $Z$ axis during cutting. The use of this strategy allowed the required amount of material to be removed while reducing the cutting edge wear. Changing the position of the milling cutter in $Z$ axis and at the same time reducing the number of tool entries into the workpiece not only reduced the wear of the cutting edges, but also reduced the cutting time.

\section{REFERENCES}

[1] Burek J., Żyłka Ł., Gdula M., Płodzień M. „Wpływ orientacji osi freza toroidalnego na składowe siły skrawania w pięcioosiowej obrób-ce łopatki turbiny ze stopu INCONEL 718". Mechanik. 8-9 (2015): 764-774, http://dx.doi.org/10.17814/mechanik.2015.8-9.489.

[2] Chodorowski J., Ciszewski A., Radomski T. „Materiałoznawstwo lotnicze”. Oficyna Wydawnicza Politechniki Warszawskiej, Wrocław 2003.

[3] Ducros C., Sanchette F. "Multilayered and nanolayered hard nitride thin films deposited by cathodic arc evaporation. Part 2: Mechanical properties and cutting performances". Surface and Coatings Technology. 201 (2006): 1045-1052, https://doi.org/10.1016/j.surfcoat.2006.01.029.

[4] Jafarian F., Amirabadi H., Sadri J. "Experimental measurement and optimization of tensile residual stress in turning process of Inconel 718 superalloy". Measurement. 63 (2015): 1-10, https://doi.org/10.1016/j.measurement.2014.11.021.

[5] Matras A., Zębala W., Ślusarczyk Ł. „Wpływ modelu materiałowego na wyniki badań symulacyjnych frezowania stopu Inconel 718". Mechanik. 10 (2016): 109-114, http://dx.doi.org/10.17814/mechanik.2016.10.402.

[6] Nath Ch., Brooks Z., Kurfess T.R. „Machinability study and process optimization in face milling of some super alloys with indexable copy face mill inserts". Journal of Manufacturing Processes. 20 (2015): 8897, https://doi.org/10.1016/j.jmapro.2015.09.006.

[7] Sharman A.R.C., Hughes J.I., Ridgway K. "The effect of tool nose radius on surface integrity and residual stresses when turning Inconel 718 ${ }^{\mathrm{TM}}$. Journal of Materials Processing Technology. 216 (2015), s. $123-$ 132, https://doi.org/10.1016/j.jmatprotec.2014.09.002.

[8] Szablewski P., Weiss E., Chwalczuk T. „Rozwój obróbki materiałów trudnoskrawalnych”. Mechanik. 89 (2016): 1208-1209, http://dx.doi.org/10.17814/mechanik.2016.8-9.321.

[9] Tian X., Zhao J., Zhao J., Gong Z., Dong Y. „Effect of cutting speed on cutting forces and wear mechanisms in high-speed face milling of Inconel 718 with Sialon ceramic tools". International Journal Advances Manufacturing Technology. 69 (2013): 2669-2678, https://doi.org/10.1007/s00170-013-5206-4. 